\title{
CREATIVE MARKETING IN SERVICES
}

\section{MUSTAFA BOZ}

RECEIVED

ACCEPTED

JEL

CLASSIFICATION

KEYWORDS

ABSTRACT
Canakkale Onsekiz Mart University, TURKEY

e-mail:m.b.istanbul@gmail.com

10 January 2016

1 March 2016

M31, M37, 031, O35

Creative Marketing, Marketing in Services, Destination Marketing, Social Media

Increasing worldwide competition due to liberal economies and globalization, rapid and continous development in communication and information technologies have created a new type of consumer. Today, consumers are more demanding. They want to be more informed, more valuable, and taken into consideration. Even, they wish to play an active role in creating and marketing of products. All these have changed marketing concept and perception. Marketing and communication managers must plan and apply creative and contemporary marketing strategies and media to be able to reach new type of consumers and to be able to compete.

This conceptual study is consisted of mainly two parts. In the first part; creativity concept, and characteristics of creativity in marketing are tried to explained. In the second part; the concept and importance of services marketing is mentioned and some examples are given from creative marketing practices in services. Such as; one of the most creative, destination marketing campaigns using the social web, "The Best Job in the World" campaing of Tourism Queensland. Starbucks, the world's most engaged brand online and a social media role model in service business.

\section{Introduction}

In a new age, with new consumers, marketing managers need to shift away from a features-and-benefits approach, as advocated by traditional approaches to consumer experiences. They need to consider new concepts and approaches which capitalise on the opportunities offered by these new consumers (Williams, 2006). New consumers are more informative and more demanding. As Boone et al. (2010) state "customer loyalty is the 
watchword of 21st-century marketing. Individual consumers and business purchasers have so many goods and services from which to choose - and so many different ways to purchase them - that marketers must continually seek out new and beter ways to attract and keep customers". Unfortunately, marketing programs for many established products fall short in terms of creativity. As a result, manufacturer - initiated price wars have arisen in product categories ranging from disposable diapers to mutual funds (Andrews, Smith, 1996). On the other side; in recent years a growing number of economic studies worldwide have demonstrated the impressive contribution of creative enterprises to economic growth, jobs and wealth creation. Creative enterprises are increasingly considered today as new tools for sustainable development (Greffe, 2006). Creativity offers insights and new ideas that eventually become innovative solutions to problems. Combined with clever, skillful marketing strategies, creative ideas become commercial successes that lead to dynamic societies, political influence and economic development (Pitta et al., 2008). As Dragoon (2010) points out "Creativity is perhaps the key attribute most needed and desired to address our 21 st century business challenges". Thus; creativity in marketing is the most important issue in the new business environment.

\section{Creativity concept in marketing}

Levitt (1983) determines that "in marketing, the main object is to get and keep a customer, and also to get existing buyers to prefer to do business with you rather than your competitors. In marketing therefore, the imagination must constantly focus on that objective". Every company must serve customer needs - create customer satisfaction - to succeed. Boone et al. (2010) call customer satisfaction as an art because it requires imagination and creativity and a science because it requires technical knowledge, skill, and experience. Marketing strategies are the tools by which business people identify and analyze customers' needs and then inform these customers about how the company can meet those needs. Tomorrow's market leaders will be companies that can make the most of these strategies to create satisfied customers.

The essence of competition is differentiation: providing something different and better than your competitors. Sometimes an obvious functional difference doesn't sell unless it is also presented or positioned differently (Levitt, 1983). As the competitive landscape has changed, so too has management's response to those changes (Coy, 2000). Rapidly changing business landscapes create new challenges for companies, whether they are giant multinational firms or small companies, profit-oriented or not-for-profit organizations. Companies and organizations must react quickly to shifts in consumer tastes, competitive offerings, and other market dynamics. Fortunately, information technologies give organizations fast new ways to interact and develop long-term relationships with their customers and suppliers. In fact, such links have become a core element of marketing today (Boone et al., 2010). As a result, businesses are clamoring for creative breakthrough ideas, products, and services that provide significant competitive advantages (Titus, 2007). Today, creativity and marketing imagination are essential core competencies for marketers (Jaskari, 2013).

\section{Characteristics of Creativity in Marketing}

John Dragoon (2010), senior vice president at Novell points out that "creativity is needed at all levels within an organization. Like many others, Novell has a company-wide "Incubator" program where we encourage and reward employees who submit business proposals for new solutions they feel deserve development funding. In the last year, two completely original ideas have been taken to market. This scenario demonstrates how product development 
initiatives can be driven by many individuals across an organization and how a creative approach embraced by everyone within a company can ultimately play a significant role in driving market leadership".

The 21st century has brought both opportunities and challenges in this global, boundaryless world. Technological advances continuously revolutionize marketing. Technology can also open up entirely new markets. Cell phones have helped bring the entire continent of Africa into the world marketplace. With a cell phone in hand, farmers no longer have to trek miles to a pay phone to negotiate prices for their goods. Marketing managers face a dynamic and interconnected international environment. As such, they have to consider the many opportunities and threats that Web 2.0, social media, and creative consumers present, and marketing managers need to learn to work within the resulting respective shifts in loci of activity, power, and value (Boone et al., 2010; Berthon et al., 2012). Borrett, \& Barreto, 2011 offer a model, Building the Capabilities: The 4Ts Creativity in Marketing Framework. Building these capabilities requires new ways of working, mindsets and behaviours. The 4Ts framework, illustrated in Figure 1, supports the development of the skills and discipline required, by reflecting four key enablers to releasing creativity in marketing.

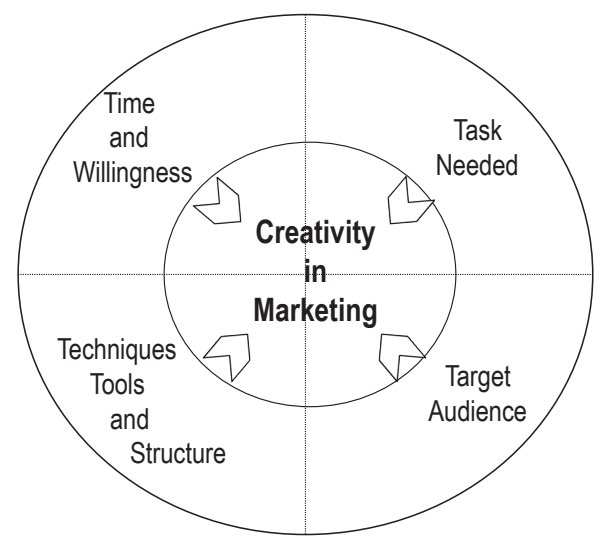

Figure 1. The "4Ts Creativity in Marketing Framework"

Source: Borrett and Barreto (2011).

Work environment also affects the creativity potential of a company. Main points to increase and encourage creativity in a company are (Sefertzi, 2000; Siedel, Rosemann, 2008; Burbiel, 2009).

- supporting participatory decision-making and employees' contribution,

- enhancing creativity, experiment with new ideas,

- allowing creative freedom, taking initiatives,

- managing creative risk, keeping control of the creative process,

- supporting flexible resource allocation,

- adhocracy perception,

- cooperative - team perception,

- procedural justice, 
- keeping communication channels open, knowledge sharing,

- awarding of employees who contribute,

- contacts with external sources of information.

Companies which depend on continuous creativity can benefit if they are located in cities or regions that attract "creatives". Creatives are those individuals whose viewpoint, skill, motivation and need to succeed allow them to develop innovations of value. To grow and prosper, developed and developing societies must nurture, attract, connect and retain creative "knowledge workers" (Pitta et al., 2008). Creativity and innovation are strategic tools that allow companies to overcome the many difficulties in preparing for the future (Reisman, 2013).

\section{Services Marketing}

The service sector is a growing part of the economy in many countries. In the early 1970s the marketing of services started to emerge as a separate area of marketing with concepts and models of its own geared to typical characteristics of services (Grönroos, 1997). Service firms also play a major role in today's global marketplace. As economies advance, a growing proportion of their activities are focused on the production of services. Many market offerings consist of a variable mix of goods and services. The U.S. economy today consists of a 7030 services-to-goods mix. Services include airlines, hotels, maintenance, repair etc., as well as professionals such as accountants, lawyers, engineers, and doctors. Many market offerings consist of a variable mix of goods and services (Kotler, 2002).

Service markets have never been larger, competition in services has probably never been more intense, and net employment growth within developed economies is almost exclusively derived from services (Lovelock, Gummesson, 2004). New infrastructures - notably e-mail, internet, powerful laptops, and mobile telephony - but the service applications were more hype and odd cases than marketing reality. In the 2000s, although the bulk of services remain the same as basic customer needs have not changed dramatically, the ordering and production of many services have changed. IT applications have matured into working services and new services have spawned totally new markets and strategies, and will keep doing so (Gummesson, 2007). Internet technology offers the potential for creating new business models, radical new approaches to delivering information- based services, and newways of relating to customers (Lovelock, Gummesson, 2004).

\section{Creative Marketing Practices in Services}

Companies, corporations, foundations etc. rely on creativity at all levels to attract the attention and appreciation of their target groups. Herebelow some successful examples mentioned.

Starbucks - Every business can learn from another, especially if a particular business is one that has displayed tremendous success over the years. The Starbucks Corporation and its successful marketing strategies are definitely something that anyone interested in business can learn about (voteforus.com, 2014). Starbucks have been successfully executing their social media marketing plan since the first days of social media and social commerce. Their strategies have played a significant role in their growth. Starbucks rode the baby boomer trend in the 1990s, the swelling ranks of mid-age professionals that created the need for a third place, 'an affordable luxury' where people could share and enjoy a cup of coffee with friends and colleagues, away from work and home. According to Schoultz (2014), the company has inserted itself into the American urban landscape more quickly and craftily than any retail company in history. It has forever changed the way, companies market themselves 
to customers. The company continues to focus on its original product bundle that includes good coffee, quality service, and a nice environment to hang around. They keep their attention on the details of great execution and service. One of the earliest adopters of the use of social media for marketing and social commerce, Starbucks has certainly taken a leadership position. Their social media strategy is built around their company web site and 6 additional social platforms, including Twitter, Facebook, Pinterest, G+, Youtube, and My Starbucks Ideas.

McDonald's - Real-Time Marketing Learnings: Through the use of an optimized call to action and creative messaging, the fast food chain McDonald's agency H\&L Partners was able to increase performance for a localized campaign. McDonald's launched a digital campaign to drive more brand awareness to their breakfast sandwiches and coffee in the St. Louis, Missouri market. The campaign featured social media tie-ins with the ability to tweet and Instagram to share photos and comments on how a consumer's morning was going. After the initial launch drew minimal clicks, H\&L Partners and PointRoll recommended utilizing a dynamic text field to revise and optimize the call to action (CTA). The stronger CTA, "Click to tell us about your morning, STL" and subsequent updates increased performance significantly, driving users to the brand's \#GoodMorningSTL website where they could share and view other user's McDonald's breakfast photo submissions. The Dynamic call to action drove higher results than the initial impressions:

- McDonald's saw an overall campaign click-thru rate increase of $65 \%$.

- Dynamic campaign click-thru rate lift of $112 \%$.

- Instagram click-thru rate lift of $124 \%$.

- Twitter click-thru rate lift of $110 \%$ (Pointroll, 2014).

Tourism Queensland - A very genuine and fantastic campaing was launched by Digital Marketing, Tourism Queensland, Australia to promote and to market the Great Barrier Reef internationally: "The Best Job in the World". PhoCusWright Inc. (2011) admits that "The best job in the world," represents one of the most creative, recent destination marketing campaigns using the social web. Vision of Tourism Queensland is to be the global leader in destination management and champion of world's best practice in sustainable tourism. The mission is to enhance the development and marketing of Queensland tourism destinations in partnership with industry, government and the community (Linkedln.com, 2011). Tourism Queensland Chief Executive Officer Anthony Hayes (2009) says " the Best Job in the World campaign had received a phenomenal response and achieved its aim of drawing the world's attention towards Queensland's Islands of the Great BarrierReef. The campaign has opened Queensland's doors to the world". The campaign reached $\$ 390$ million AUD of publicity globally, tourism also increased by $20 \%, 50 \%$ of Australia trips now include a Queensland component (Boz, Unal, 2011; Kissane, 2015).

Dell - Dell's Ideastorm (www.ideastorm.com) generates ideas on how to improve the business and uses systemized suggestion boxes. Customers, and even non-customers, can suggest new products and features, as well as better ways of running the business, eg. improvements in their processes. Dell have earned $\$ 10$ million from the early stages of Ideastorm. This may seem tiny to a company of Dell's size but, remember, this is brand engagement, a form of brand promotion to the brand zealots, and it also contributes something to the bottom line (Smith, Zook, 2011).

Martha Stewart - Do-It-Yourself (DIY) strategies; for example, the Martha Stewart television program and magazine provide cooking and homemaking tips and tricks for consumers to perform by themselves. In the design stage, consumers can play a part in codesigning products or services; for instance, global fashion brands such as Reebok, Adidas, and Ralph Lauren have let consumers participate in designing their own collections. In the initiating 
phase, consumers can engage in expressing their unfulfilled demands; several companies collect this information from online channels such as blogs and customer review sites (Nuttavuthisit, 2010).

\section{Conclusions}

Competition becomes tougher day by day in business life. Even local businesses have to compete with new businesses and competitors from all over the world. Because of rapid technologic developments in all areas like communication and transportation, liberalization of economies, free movement of capital around the world, more and more commodity and service businesses are now marketing across national borders. Consumers also change, they become more demanding, more informative and active. As a result of these changes, in the 21 st centrury, marketing also transforms from traditional marketing applications and strategies to creative marketing application and strategies. Businesses have to find new and more creative marketing strategies to be able to compete, to grow and to survive. New marketing tools for creative business for example; a well designed and directed company website, e-mail, social media intermediaries such as Facebook, Twitter, YouTube, Flickr, Linkedln, Pinterest, g+ offer opportunities for small, medium or huge companies. For example; the Best Job in the World campaing of Tourism Queensland obtained 390 million AUD of publicity globally with a relatively small \$1.2 million budget (Kissane, 2015). Schultz points out that the social media is a cost-effective way of engaging with the customers. Starbucks has with almost 40 million worldwide fans on Facebook as of 2012, a leading company on Twitter and Foursquare. And what that has done, it has given the ability to lower cost of customer acquisition in terms of traditional advertising and build a more enduring, emotional relationship with customers (Perepu, 2013: p. 14). Internet marketing, Guerrilla marketing, Mobile marketing, Real-time marketing, Experiential marketing, Relationship marketing techniques are some other tools for creative marketing strategies.

\section{References}

Andrews, J. \& Smith, D.C. (1996). In Search of the Marketing Imagination: Factors Affecting the Creativity of Marketing Programs for Mature Products. Journal of Marketing Research, XXXIII, 174-187.

Berthon, P.R., Pitt, L.F., Plangger, K. \& Shapiro, D. (2012). Marketing Meets Web 2.0, Social Media, and Creative Consumers: Implications For International Marketing Strategy. Business Horizons, 55, 261-271.

Boone, L.E., Kurtz, D.E., Mackenzie, H.F. \& Snow, K. (2010), Contemporary Marketing. 2nd Canadian Edition. Toronto: Nelson Education Inc.

Borrett, M. \& Barreto, R. (2011). Creativity in Marketing: An Acquired Skill. Brand Learning enclosed.

Boz, M. \& Unal, D. (2011). Successful Promotion Strategy in Destination Tourism Marketing Through Social Media; Queensland, Australia Case. Regional Science Conference with International Participation with the Theme Stable Local Development Challenges and Opportunities. 3-4 June 2011. Peja, Republic of Kosova.

Burbiel, J. (2009). Creativity in research and development environments: A practical review. Int. Journal of Business Science and Applied Management, 4 (2).

Coy, P. (2000, August 28). The 21st century corporation: The creative economy. Business Week, 77-82. Cited from Titus, P.A. (2007). Applied Creativity: The Creative Marketing Breakthrough Model. Journal of Marketing Education, 29 (3), December 2007, 262-272.

Dragoon, J. (2010). What Is Creativity's Value--In Marketing, In Business? Retrieved 10/04/2010 from http://www.forbes.com/2010/10/04/ facebook-zuckerberg-twitter-wendy-kopp-creativity-advertising-cmo-network.html (10.02.2014).

Greffe, X. (2006). Managing Creative Enterprises. Creative industries - Booklet No. 3. World Intellectual Property Organization.

Grönroos, C. (1997). Keynote Paper: From Marketing Mix To Relationship Marketing - Towards a Paradigm Shift in Marketing. Management Decision, 35 (4), 322-339. 
Gummesson, E. (2007). Exit Services Marketing - Enter Service Marketing. The Journal of Customer Behaviour, 6 (2), $113-141$.

Hayes, A. (2009). Best Job in the World bursts onto the ATE stage. Retrieved from Tourism Queensland, http://www.tq.com.au/ tqcorp_06/fms/tq_corporate/international/Microsoft $\% 20$ Word\%20-\%20ATE\%20Daily $\% 20 \% 202009 \% 20-\% 20$ Best $\% 20 J$ Jb $\% 20$ in $\% 20$ the $\% 20$ World\%20media\%20release.pdf (10.02.2012)

Jaskari, M.M. (2013). The Challenge of Assessing Creative Problem Solving in Client-Based Marketing Development Projects A SOLO Taxonomy Approach. Journal of Marketing Education, 35 (3), 231-244.

Kissane, D. (2015). Case Study: The Best Job in the World. 22.01.2015. Retrieved from http://www.doz.com/content/case-study-bestjob-world (21.3.2016).

Kotler, P. (2002). Marketing Management. Millenium Edition. Custom Edition for University of Phoenix. ISBN 0-536-63099-2 BA 993095 (15.03.2014).

Levitt, T. (1983). The Marketing Imagination (Excerpt). New York-London.

Linkedln.com. (2011). About Tourism Queensland. Retrieved from Linkedin.com: http://www.linkedin.com/company/tourismqueensland?trk=ppro_c (10.02.2012).

Lovelock, C. \& Gummesson, E. (2004). Whither Services Marketing?: In Search of a New Paradigm and Fresh Perspectives. Journal of Service Research, 7, 20.

Nuttavuthisit, K. (2010). If You Can't Beat Them, Let Them Join: The Development Of Strategies To Foster Consumers' Co-Creative Practices. Business Horizons, 53, 315-324.

Perepu, I. (2013). Starbucks: Brewing Customer Experience through Social Media. IBS Center for Management Research, 513-001-1.

PhoCusWright Inc. (2011). Effective Tourism Marketing In Today's Digital World; Tourism Queensland - A Compelling Case Study. Millennium Foundation, Retrieved from http://www.millenniumfoundation.org/mutualise/uploads/assets/the_phocuswrightconference_program_ccb05095dc79a8082a70 1f89a78cf89047330c31.pdf (1.04.2012).

Pitta, D.A., Wood, V.R. \& Franzak, F.J. (2008). Nurturing an Effective Creative Culture within a Marketing Organization. Journal of Consumer Marketing, 25 (3), 137-148.

Pointroll (2014). Real-Time Marketing, Dynamic Cr eative Optimization \& the Empowered Marketer Understanding the Intersection of Data, Media and "Big" Creative.

Reisman, F. (2013). Introduction To Creativity: Process, Product, Personality, Environment \& Technology. Chapter 1. (Guest Editor) Reisman, F. Creativity: Process, Product, Personality, Environment \& Technology. International Conference on Knowledge, Innovation \& Enterprise, KIE Conference Books.

Schoultz, M. (2014). Starbucks Marketing Strategy: Making Social Media A Difference Maker. Retrieved from http://www. digitalsparkmarketing.com/creative-marketing/social-media/starbucks-marketing (2.05.2014).

Sefertzi, E. (2000). Creativity. Report produced for the EC funded Project. January 2000.

Seidel, S. \& Rosemann, M. (2008). Creativity Management - The New Challenge for BPM. BPTrends, May 2008. Retrieved from http:// www.bptrends.com/publicationfiles/Three\%2005-08-ART-CreativityManagement-Seidel-and-Rosemann-final.pdf (4.01.2016).

Smith, P.R. \& Zook, Z. (2011). Marketing Communications. Integrating off line and online with Social Media. Kogan Page, Fith edition.

Titus, P.A. (2007). Applied Creativity: The Creative Marketing Breakthrough Model. Journal of Marketing Education, 29 (3), $262-272$.

voteforus.com (2014). Starbucks Marketing Strategy Unconventionally Effective. Retrieved from http://www.voteforus.com/ starbucksmarketingstrategy.html (20.3.2014).

Cite this article aS: Boz, M. (2016). Creative marketing in services. European Journal of Service Management, 17 (1), 5-11. DOI: 10.18276/ejsm.2016.17/1-01. 
